\title{
Compromesso astorico: the role of the Senate after the Italian constitutional reform
}

\author{
GEORGE TSEBELIS* \\ Department of Political Science, University of Michigan, Ann Arbor, MI, USA
}

\begin{abstract}
The article examines the content of the constitutional amendments with respect to the Senate. While symmetric bicameralism would be abolished with respect to policymaking, it would be preserved and even exacerbated with respect to constitutional revisions. The consequences of the first would be a reduction of the number of institutional veto players, which would lead to the facilitation of policy change, and an increase in the power of the government (who is the agenda setter). The content of the new policies remains unknown, as are the economic consequences of the proposed changes. Constitutional revisions would become more difficult, because the ideological distance between the Chamber of Deputies and Senate would be likely to increase (because of the mode of selection of Senators), while article 138, which specifies the requirements for amendment to the constitution, would remain the same. As a result, the role of the Italian Constitutional Court would also likely increase.
\end{abstract}

Keywords: Italy; parliament; referendum; constitution

\section{Introduction}

In October 2015, the Italian Senate voted 179-10 in favor of the largest reforms to its constitution since its ratification in 1947. Amidst a boycott by over a hundred senators, the vote approved measures that would drastically weaken bicameralism in Italy, stripping the Italian Senate of its ability to veto most types of legislation. While only one step in the constitutional amendment process, the vote represented a key victory for proponents of the reforms, who believed the changes would finally address the legislative gridlock and governmental instability that has long beleaguered Italy's political system. Said Prime Minister Renzi of the successful vote, 'You can agree or not with what we're doing, but we're doing it: the long season of inconclusive politics is over' (Follain, 2015). Minister of Reform Maria Elena Boschi took it a step further, calling the reforms a 'Copernican revolution' for Italy (The Economist, 2015).

The political history surrounding the constitutional revisions has not yet been systematically detailed or analyzed. It would be interesting to know why, for example, Berlusconi agreed to the reforms before asking his supporters to leave

*E-mail: tsebelis@umich.edu 
the Senate. ${ }^{1}$ And why did the members of the Senate agree to vote for a reduction of their own powers? Historical examples of this sort are rare (the reduction of the powers of the House of Lords comes to mind), but in these occasions, a serious threat of appointment of new members was a necessary part of the deal that produced the results.

But in the Italian case, the reduction of powers of the Senate on policy matters was accompanied by the preservation of symmetric bicameralism on constitutional issues. This ambiguous and inconsistent choice was included in the initial text of the committee of 'wise men' reporting on 15 April 2014. ${ }^{2}$ Newspaper informa$\operatorname{tion}^{3}$ has shown Renzi denying that he ever said or thought to abolish the Senate, while others argue that this was a 'plan b'. If this information is correct, the wise men plan was a compromise among the current constitutional provisions and an alternative, more radical approach: a 'compromesso astorico'. The compromise adopted achieves its goal in one dimension (policy), but as this article will demonstrate, it compounds the situation in another (constitutional amendment). It will be shown that it neither takes into consideration the historical experiences of other countries, nor does it consider the long-run impacts of increases in constitutional rigidity.

The political history of the aforementioned events should cast important light on the political dynamics leading to this compromise. In this article, however, the analysis works backward, looking at the institutions themselves and examining the ramifications of the impending constitutional changes. To do so, the article uses Veto Players theory to assess the effects of Italy's reforms on its constitutional revisions process, policy-making outcomes, and the balance of power between its governing institutions. More specifically, I argue that while Italy's constitutional reforms will achieve the goal of greater policy change in the legislature (by decreasing the number of relevant veto players), they will render constitutional revisions more difficult and strengthen the role of the court in constitutional interpretation (while decreasing its power in statutory interpretation). In this sense, reformers' ultimate goals have been only partially achieved, as legislative flexibility will be escorted by constitutional rigidity. The goal of the article is precisely to demonstrate this contradiction, and the only partial achievement of the goal of increasing the potential for change.

The analysis proceeds as follows. First, I review the theoretical effects of full bicameralism in the abstract to establish a baseline account for why Italy has struggled with legislative gridlock for so long. Then, I discuss how each of

\footnotetext{
${ }^{1}$ Berlusconi's stated reason was that he considered Renzi's choice of Mattarella for President to be a rupture of a pact.

${ }^{2}$ http://www.osservatorioaic.it/relazione-finale-del-gruppo-di-lavoro-sulle-riforme-istituzionali.html

${ }^{3}$ See http://www.lastampa.it/2015/09/17/italia/politica/riforma-in-aula-test-sui-numeri-per-il-governooYAlJVd7jcsoJhsShUU0cM/pagina.html, and http://www.corriere.it/politica/15_settembre_17/renzi-vuoleblindare-pd-la-conta-direzione-ma-c-anche-piano-b-abolire-palazzo-madama-31792dc6-5cff-11e5-aee5-7e43 6a53f873.shtml I thank Francesco Zucchini for providing this information.
} 
the proposed reforms changes this basic arrangement. Next, the second section shows how the Senate's new system of indirect, regional election would be likely to render the process of constitutional revision more difficult than anticipated. The third section, however, argues that reformers would, by and large, achieve their goal of decreased gridlock in regular policymaking, as the proposed reforms essentially remove the Senate as a veto player. I remain agnostic about the impacts this change would have on economic outcomes in Italy. Finally, the last section argues that, while the judiciary's role in regular policymaking may decrease, its ability to alter the constitution through the process of interpretation would be enhanced by the reforms. The analysis then closes with a summary of conclusions about Italy's proposed constitutional reforms.

\section{Bicameralism and Italy's present system of government}

Perhaps the leading feature of the Italian constitution that has led to legislative gridlock is its system of full and symmetric bicameralism. Because both chambers of the legislature must approve identical bills in order for them to become law, the legislature tends to be unsuccessful in passing consequential legislation. This is not, however, a feature that is unique to Italy's system of full bicameralism. Rather, bicameralism is known to generally reduce policy change, as it adds an additional veto player to a system of governance. Figure 1 depicts this dynamic. In Figure 1a, bill passage requires only a simple majority of all legislators in the upper and lower chambers: four out of six of the depicted legislators. This arrangement produces a winset [W(SQ); the set of policies that the hypothetical unicameral legislature prefers to the status quo] that includes the three shaded petals in Figure 1a. In Figure 1b, however, the legislature is now bicameral: members of parliament are divided into upper (U) and lower chamber (L), and concurrent majorities of both chambers are required in order for a piece of legislation to pass. Under this arrangement, W(SQ) shrinks to just one of the three petals present in Figure 1a. In other words, by adding a second chamber as a fully autonomous veto player within the legislative branch, the set of bills that could conceivably beat the status quo shrinks, and policy change abates (Tsebelis and Money, 1997). This reduction in the size of the winset has an additional, important consequence: the role of the agenda setter is reduced under bicameralism. Indeed, the government of a parliamentary system has less prerogative when confronted with a bicameral legislature than when confronted with a unicameral one.

As is the case with all other veto players, however, the distance between chambers in a bicameral system also restricts the level of policy change possible within a legislature. As Madison describes it in the Federalist Papers, 'the improbability of sinister combinations will be in proportion to the dissimilarity in the genius of the two bodies' (Hamilton et al., 1961 [1787-1788], 379, no. 62). The argument is presented with contemporary terminology in Figure 2. Here, the lower chamber (L) 

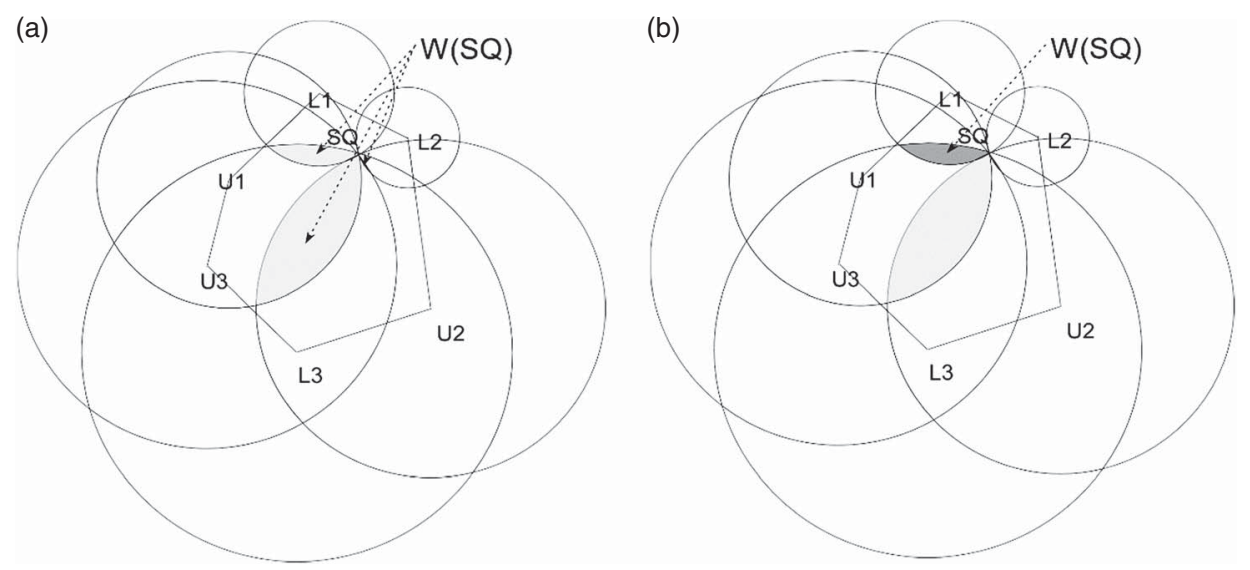

Figure 1 Winsets under a unicameral and bicameral arrangement. (a) Winset under a unicameral arrangement, (b) winset under a bicameral arrangement.

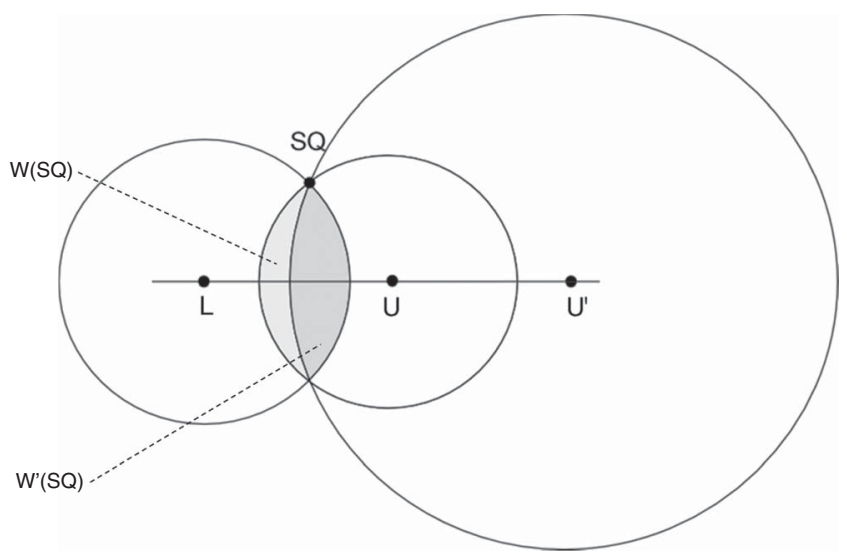

Figure 2 Winset of veto players (VPs) L and U' is contained within winset of VPs L and $\mathrm{U}$.

and the upper chamber (U) combine to create a winset, W(SQ), represented by the lighted shaded region. However, when the upper chamber shifts further away from the lower chamber (U'), the winset shrinks to the darkly shaded region. Lower and upper chambers may drift apart for any number of reasons, such as differences in election cycles or the size of their districts. Regardless of the reason, however, a growing distance between the chambers will exacerbate bicameralism's quality of reducing policy change.

Illustrated another way, bicameralism works in much the same way as a qualified majority in a unicameral legislature. In an exchange that has since been largely lost 


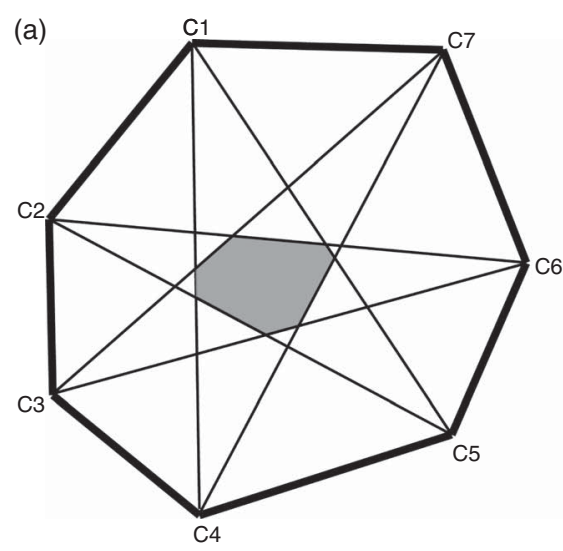

(b)

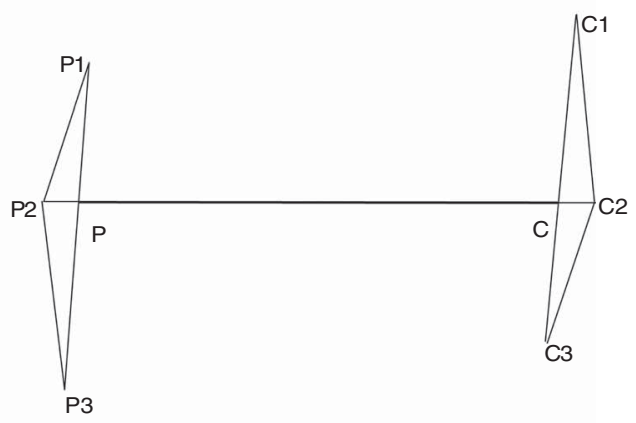

Figure 3 Cores of unicameral legislature with qualified majority and bicameral legislature. (a) Winset under a unicameral arrangement with a 5/7ths majority requirement, (b) winset under a bicameral arrangement.

(possibly in World War II, see McGrath, 1983; McLean and Urken, 1992), Madison and Italian doctor (and American apologist) Philip Mazzei debated the merits of their favored systems: the first arguing in favor of bicameralism, and the second (citing personal correspondence with Marquis de Condorcet) in favor of unicameralism with qualified majorities. Figure 3 depicts the essence of what might have been their arguments in modern political science language. In the first half (Figure 3a), I present the 'core' [i.e. the set of status quo policies that can never be overcome; see Tsebelis (2002) for greater detail] of a seven-person legislature under a $5 / 7$ ths qualified majority requirement. ${ }^{4}$ Each line represents a different five-person coalition that might support a particular bill. When one accounts for all possible five-person coalitions, the intersection of these coalitions (the darkened center in Figure 3a) represents the set of status quo policies that can never be successfully changed - the core of this qualified majority, unicameral legislature. Policies under this configuration will possess at least two features. First, policies will be concentrated at the center of the political spectrum, as depicted in Figure $3 \mathrm{a}$. Second, policies will change less frequently in the qualified majority case than in the simple majority one, all else being equal.

Bicameralism, depicted in Figure 3b, produces a different shaped core. In this scenario, two chambers (P and $\mathrm{C}$ ) must vote in favor of a bill in order for it to pass.

\footnotetext{
${ }^{4}$ In all my discussions in this article I will be using the concept of the core of a unicameral or bicameral legislature or a political system in general. For all the cases I examine the core exists and the logic of the argument can be demonstrated in a straightforward way. It is, however, possible in policy spaces of extremely high dimensionality that the core ceases to exist. The arguments still hold as I have demonstrated in Veto Players (Tsebelis, 2002).
} 
Much as in the case of the qualified majority scenario, legislators P1, C1 prefer policies above line segment P2C2, legislators P3, and C3 prefer policies below, while legislators $\mathrm{C} 2$ and $\mathrm{P} 2$ are indifferent. Thus, the core of this legislature - the set of status quo policies that can never be defeated - is the line segment PC. This result produces a core with a different shape (a straight line in two dimensions), but it is still centrally located between the preferences of the two chambers. In other words, the unicameral, qualified majority legislature and the bicameral legislature will both result in policies that lie in the center of the political spectrum. Furthermore, both arrangements decrease the amount of possible policy change, relative to the simple majority unicameral case.

In conclusion, because bicameralism adds an institutional veto player to a political system, it is bound to decrease policy change - a result that is exacerbated when the chambers drift apart. It is also likely to concentrate a country's policies into a small region within the center of a country's ideological spectrum. These theoretical results explain Italy's history of 'inconclusive politics', as Prime Minister Renzi describes them. For much of Italy's history under the 1947 constitution, the Senate did not restrict the set of feasible outcomes (winset of the status quo) because of its ideological make-up per se: after all, it had the same composition as the Camera dei Deputati. Instead, lack of political alteration (dominance of the DC throughout the period) as well as multiple veto players (either in the form of compromesso storico or pentapartito governments) led to 'immobilismo'. The electoral reforms in 1993 and, even more in 2005 , created ambiguous results. On the one hand, alternation in the Italian political system reduced of the number of partisan veto players, since the winning coalitions were either center-left or center-right and did not include parties on both sides of the spectrum. On the other hand, in the 2005 electoral reform, the bonus distribution at the national level for the House of Deputies and at the regional level for the Senate, in combination with 'perfect bicameralism', increased the number of institutional veto players. The resulting complication was compounded by the intervention of the Constitutional Court, which declared the electoral reforms unconstitutional.

This ambiguity generated the present need for reform. The remainder of the paper examines the results, arguing that although the proposed reforms would likely achieve their goal of decreasing the difficulty of policy change, they would also render constitutional revisions more difficult and increase the role of the judiciary in constitutional interpretation.

\section{Consequences for constitutional revision}

While Italy's reforms drastically decrease the powers of the Senate in most legislative situations, one area in which full bicameralism remains is constitutional reforms and constitutional laws. According to the Italian Constitution (Part II, Title VI, Section II, article 138), the Senate indeed plays an important role:

Laws amending the Constitution and other constitutional laws shall be adopted by each House after two successive debates at intervals of not less than three months, and shall be approved by an absolute majority of the members of each House in 
the second voting. Said laws are then submitted to a popular referendum when, within three months of their publication, such request is made by one-fifth of the members of a House or five hundred thousand voters or five Regional Councils. The law submitted to referendum shall not be promulgated if not approved by a majority of valid votes. A referendum shall not be held if the law has been approved in the second voting by each of the Houses by a majority of two-thirds of the members.

This set of provisions specifies two alternative procedures for constitutional revision: revisions may occur via two-third majorities in both chambers of the legislature, or by simple majorities plus a referendum. ${ }^{5}$

Figure $4 \mathrm{a}$ demonstrates the core of the first procedure for revision, two-thirds majorities in both chambers. I represent each chamber with five members (L1-5 and U1-5) and look for agreement from four out of the five members in each chamber, as four out of five most closely approximates the two-thirds majority required to successfully pass constitutional reforms under the first procedure. Under this arrangement, the pentagon $\mathrm{C}_{\mathrm{L}}$ represents the core of the lower chamber: any point outside this pentagon can be defeated by its projection on the pentagon, since four out of the five members of the lower chamber would prefer this solution. Similarly, the pentagon $\mathrm{C}_{\mathrm{U}}$ depicts the core of the upper chamber. Similar to Figure $3 \mathrm{~b}$, then, the bicameral constitutional core in this case is comprised not only of both $C_{L}$ and $\mathrm{C}_{\mathrm{U}}$, but also of the area between them (the shaded area in Figure $\left.4 \mathrm{a}\right){ }^{6}$

Figure $4 \mathrm{~b}$ captures the second possible procedure for constitutional revision: concurrent simple majorities in both chambers, plus a referendum. In this case, the bicameral core by simple majority is located along the line segment L2U2. Indeed, this line is a 'bicameral median'; that is, it has a majority of members of both houses on either side of it, like P2C2 in Figure 3. It follows that there is a majority in both houses that would prefer, over any point outside this line, its projection on the line itself. The bicameral core, however, does not extend beyond point L2 and U2: anything outside the solid line in the figure does not command a majority in one of the chambers. So, the bicameral core is the solid line between L2 and U2. In order to calculate the whole constitutional core, including the referendum requirement, one must factor in the voters (point $\mathrm{P}$ ) and expand the core. The shaded triangle depicts that addition. ${ }^{7}$

The core of the Italian Constitution exists at the intersection of the cores of the two procedures delineated in Figure $4 \mathrm{a}$ and $4 \mathrm{~b}$. Indeed, any point that belongs in

\footnotetext{
${ }^{5}$ For each one of these procedures, there are some additional constraints (i.e. double passage by the same legislature after a time interval), but these are the most important features of the two alternatives.

${ }^{6}$ In this Figure I have deliberately selected two chambers with preferences that do not overlap, in order to have a clear picture. If the preferences were overlapping, the two pentagons would come closer, and the bicameral core would shrink.

${ }^{7}$ Again, I have selected on purpose to consider distinct preferences. If the two houses come closer to each other, or if the voters have preferences similar to one of them, the triangle will shrink, but it will not affect the logic of the argument.
} 
(a)

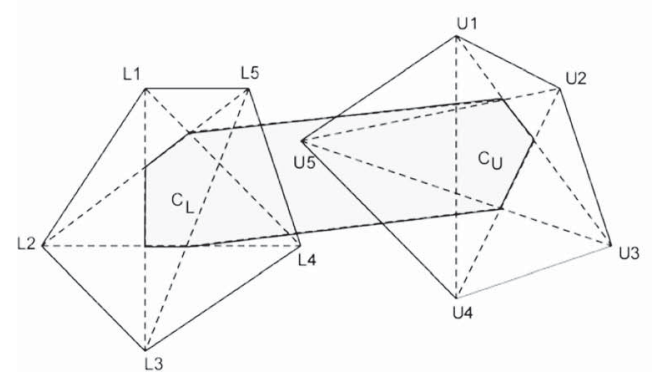

(b)

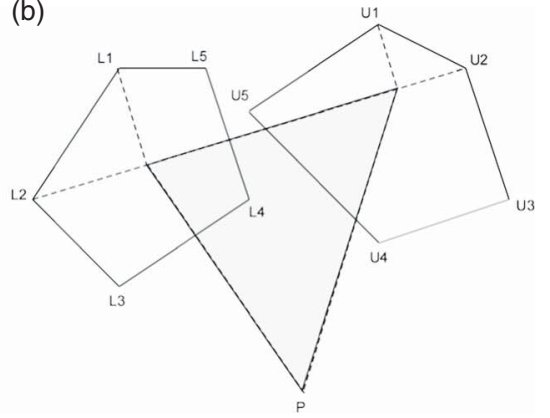

(c)

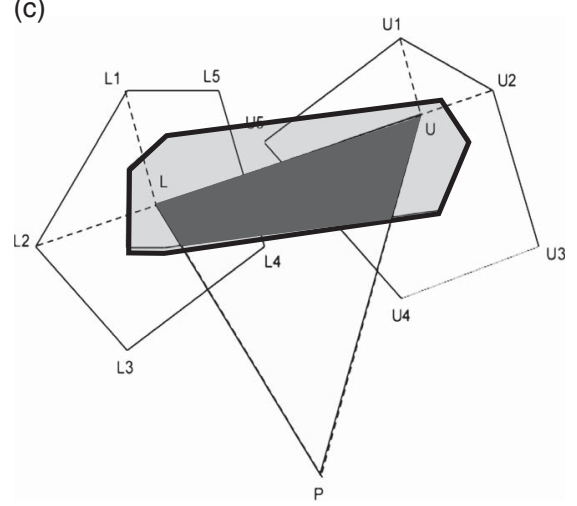

Figure 4 Constitutional core of Italy under article 138. (a) Constitutional core for revision by concurrent two-third majorities in each chamber, (b) constitutional core for revision by concurrent majorities and referendum, and (c) constitutional core (intersection of two alternative procedure cores).

only one of the procedural cores can be changed by using the alternative procedure. This intersection is represented by the darkly shaded area in Figure 4c. It cannot be a priori assessed which one of the two procedures is easier to be used. Indeed, this depends not only on the institutional rules, but also on the actual preferences of the actors. However, the system does behave in predictable ways. For example, if the preferences of the people are moved much closer to both houses than Figure 4 indicates, then it is easier to make a constitutional revision with a referendum than with two-thirds of both chambers. This seems to be the case today, because it is difficult to imagine that it would be easier to get a two-third approval of the Senate to reduce its own powers than an approval by the people. Similarly, if the two houses drift apart, the segment LU in Figure 4 will become longer, and the core will expand. Indeed, all three cores in Figure $4 \mathrm{a}-4 \mathrm{c}$ will become larger, and constitutional revision will become more difficult. This will be the case under the electoral system for the Senate created by the proposed constitutional reforms.

Under the proposed reforms, the Senate will be elected in a method far different from the lower chamber of the legislature. That is, Senators will be indirectly elected 
Table 1. Constitutional rigidity in some democratic countries

\begin{tabular}{lc}
\hline \hline Countries & Constitutional rigidity \\
\hline United States of America & 1.74 \\
Denmark & 1.51 \\
Japan & 1.51 \\
Mexico & 1.51 \\
The Netherlands & 1.51 \\
Australia & 1.275 \\
Italy & 1.275 \\
France & 1.25 \\
Ireland & 1.25 \\
Greece & 1.11 \\
Belgium & 1.01 \\
Germany & 1.01 \\
Iceland & 1.01 \\
Spain & 0.89 \\
India & 0.775 \\
Latvia & 0.687 \\
Luxembourg & 0.687 \\
Norway & 0.677 \\
Portugal & 0.677 \\
Serbia & 0.677 \\
Austria & 0.677 \\
New Zealand & 0.5 \\
\hline \hline
\end{tabular}

Bolded value underscores where Italy lay in comparison to other countries' constitutional rigidity. Italy already ranks quite highly.

through regional councils. While these changes are likely to have a wide variety of ramifications, one likely consequence will be that the difference in electoral make-up of the upper and lower chambers will increase the distance between these two constitutional veto players. As a result, constitutional change will become more difficult in Italy, increasing the rigidity of an already rigid constitution. I remind the reader that a previous attempt to change the Constitution (under the Berlusconi government) failed. The simple reason is that the required procedures discussed above make constitutional revisions difficult in Italy. For comparison, Table 1 shows measures of constitutional rigidity in different countries, indicating that Italy has one of the most difficult constitutional revision procedures (Tsebelis, 2016). An affirmative answer on the referendum regarding constitutional reform will make future constitutional revisions even more difficult to achieve, because the chambers are likely to drift apart.

\section{Consequences for policymaking}

In addition to this change to the process of constitutional revision, probably the most consequential change initiated by the proposed reforms occurs within the 
policy-making powers of the Italian Senate. Rather than maintaining a perfectly symmetric bicameral system, the reforms strip the Senate of most of its legislative veto powers, reducing the number of institutional veto players in the Italian system of governance. As a result, Italy is likely to experience far more policy change than it has in years past. In addition, the power of the government will increase (given that it controls the agenda, in a system where the number of veto players decreases). Whether or not more policy change is a positive or normative good, however, depends on one's perspective. Economists, for instance, tend to argue in favor of less policy change, which they argue allows for the stability that businesses need in order to make long-term investments. In their Nobel Prize-winning article Kydland and Prescott (1977) argue that rules are better than discretion, and that the multiplicity of veto players makes discretion impossible. Similarly, political conservatives prefer less policy change in general. Political scientists, however, argue that too much policy stasis disallows governments to adapt to an ever-changing world. Progressives adopt a similar logic in their stance in favor of more policy change. The previous analysis does not lead to a confirmation of either of these unconditional judgments. A strong Senate leads to less policy change, but the normative assessment of policy stability depends on one's assessment of the status quo.

Many empirical studies confirm the straightforward relationship between multiple veto players and policy inertia (or the absence of policy change). Kastner and Rector (2003), for example, find that democracies with more partisan veto players enact fewer changes in capital controls. Hallerberg and Basinger (1998) show that OECD countries with more veto players tend to change their corporate and personal income tax rates less (in response to the US tax reform of 1986). O'Reilly (2005) finds similar results for tariffs, as do Tsebelis (2002), Tsebelis and Chang (2004), and Giuriato et al. (2016) for labor laws, budget distribution, and fiscal forecast manipulation, respectively. All these studies indicate that increasing the number of veto players increases policy stability; however, they do not comment on the positive or negative effect (valence) of this stability.

Nevertheless, some studies do appear to underscore clear benefits or drawbacks of policy stability from veto players, but these studies typically require additional arguments above and beyond the argument of 'inertia', to substantiate their claims. Henisz (2000), Acemoglu and Johnson (2005), and Fatás and Mihov (2013), for example, all argue that policy stability leads to security and investment, ultimately increasing economic growth. Henisz and Mansfield (2006) find that increases in policy stability lead to more trade openness, because protectionism occurs in periods of recession, and many veto players make policy change (including increases in protectionism) more difficult. Roubini and Sachs (1989), Alesina and Drazen (1991), and Alesina and Perotti (1995) find that large numbers of veto players lead to increases in public debt. A more recent study by Franzese (2002), however, presents a more skeptical view of the impact of veto players on the quality of outcomes. By increasing the number of countries (in particular including Switzerland with many veto players and low budget deficits) in his sample and examining longer periods of time, Franzese finds that large numbers of veto players 
simply create inertia behind whatever level of debt a country already has, rather than uniformly increasing public debt. In this respect, Franzese's analysis is more similar to studies on inertia presented in the previous paragraph. Similarly, while some other studies do find that veto players may have an impact on the quality or content of outcomes, the relationship is rather nuanced. In responding to financial crises, for example, MacIntyre (2001) and Angkinand and Willett (2008) find that both too many and too few veto players may intensify the effects of banking crises. Indeed, while many veto players disallow a government from adequately responding to a crisis, too few veto players may create instability that undermines consumer/ business confidence.

In his 2007 book on decentralization, Treisman analyses all existing outcomesbased arguments concerning decentralization, whether in favor of (including administrative efficiency, competition among local governments, support to local economic, citizen participation and development of civic virtue, checks to the power of central government, policy innovation, diffusion of ethnic conflict) or against (pressures from central government for aid, inefficiency, and failures of fiscal coordination). His analysis is not focused on veto players, and extends both to the theoretical and the empirical level. Here are Treisman's conclusions: 'it is hard to reach any general conclusions about whether political-or administrative, or fiscal-decentralization will improve or impair the quality of government and economic performance. They will have many effects, driving in different directions on different dimensions' (2007: 274). In fact, according to Treisman, only one general conclusion may be made about decentralization: 'If political decentralization increases the number of actors whose acquiescence is needed to change policies, this will-other things being equal-tend to entrench the status quo' (2007: 274). This, of course, was the reality in Italy for several decades, and the present reforms of the electoral system and of the Senate move in the opposite direction. By removing the Senate as an institutional veto player in the system of governance, Italy will experience more policy change in the future, should it follow through with its reforms. The effect on the economy or growth, however, remains indeterminate.

\section{Consequences for institutional balance of power}

In addition to constitutional revision and policymaking, Italy's reforms would have important consequences for balance of power between branches of government if adopted, particularly between the legislature and judiciary. More specifically, this analysis argues that while the reforms would decrease the statutory interpretation power of the judiciary, they would amplify the courts' power in constitutional interpretation.

Figure 5a illustrates the intuition for the statutory component of this argument. Assume for a moment that there are three legislative veto players in Italy, such that the triangle 123 connecting the players forms the legislature's core (again, the set of 
(a)

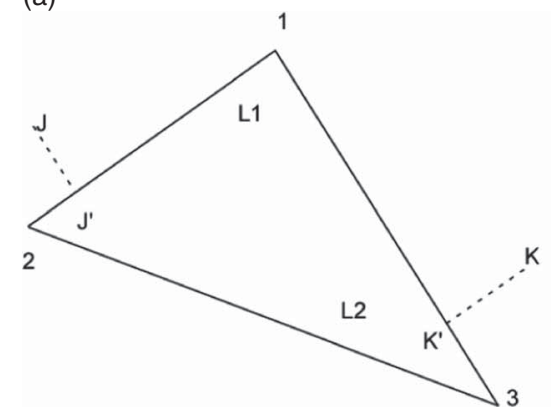

(b)

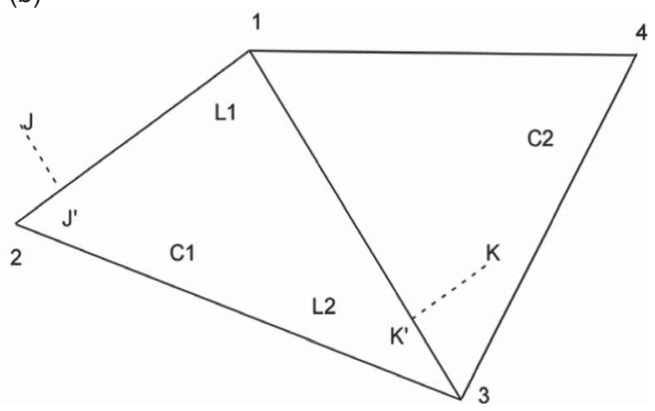

Figure 5 Policy selection by judiciary within legislative and constitutional cores. (a) Policy selection by first movers (judges) within legislative core, (b) policy selection by judges within legislative and constitutional core.

points that they cannot possibly agree to change). Assume also that $\mathrm{J}$ and $\mathrm{K}$ represent statutory interpreters (namely, judges). Under this arrangement, if a judge selects one of the points inside of the core, a legislative override is not possible. Thus, Figure 5a illustrates three different possibilities. In the first two cases, the judge's ideal points $\mathrm{J}$ and $\mathrm{K}$ are outside the legislative core, and they select the closest core point to them (J' and K', respectively). Despite the fact that these two choices are significantly different from each other, the legislative veto players are incapable of changing either of them. In the third case, the judge is located inside the legislative core, but changes her mind and moves from point L1 to point L2. Since her ideal point is inside the core, she can select it. Here again, the legislative veto players can do nothing to stop her.

In each of these cases, the power of a judge to move policy increases with the size of the legislative core. In other words, if judges hold the power to interpret existing statutes, they can move the statutes unilaterally, and then wait for the legislature to respond. The larger the core, the larger the number of status quo relocations to which the legislature will be unable to respond. This basic point explains why the judiciary's statutory interpretation powers should decrease in response to Italy's proposed reforms. As noted above, the removal of the Senate as a legislative veto player would decrease the size of the policy-making core within the legislature. As the core shrinks, the judiciary will find fewer opportunities to relocate the status quo without legislative overrule: a small core means that the legislature can retaliate on a larger number of possible statutory interpretations. Empirical evidence in favor of this argument has been presented by Tsebelis (2002) for advanced industrialized countries and from Andrews and Montinola (2004) for developing ones. Thus, the proposed reforms would decrease the courts' power in statutory interpretation in Italy.

Still, while the proposed constitutional reforms would decrease the judiciary's statutory interpretation power, they would increase the courts' power in another 
realm: constitutional interpretation. Consider now Figure 5b. Like Figure 5a, the triangle 123 represents the legislative or statutory core, and actors $\mathrm{J}$ and $\mathrm{K}$ are the 'first movers' (judges in our case, though they could also be bureaucrats). Unlike Figure 5a, however, another actor, actor 4, is present in Figure 5b. Actor 4 represents the additional approval needed for constitutional revisions - either additional approval in the legislature (up to two-thirds of both chambers), or the approval of the populace in a referendum. With the addition of 4 , the core grows - now encompassing the quadrilateral 1234. Under these circumstances, J and K's power of interpretation increases: instead of having to project her ideal point onto the perimeter of 123, K (for example) may now select her ideal point. And on constitutional issues the preferences of the Court may shift from C1 to C2 (or conversely) without the possibility of reaction by the political system (constitutional revision). As before, when the size of the core increases, the ability of the legislature (and/or other veto players) to overrule a court's decision decreases - ultimately empowering the courts.

This theory of the judiciary's power in constitutional interpretation has already received empirical support in the Italian context. Indeed, in examining unconstitutional sentence reversals by Italian courts, Santoni and Zucchini (2004; from now on S-Z) find that the number of reversals closely tracts the 'constitutional range' in Italy (i.e. the size of the constitutional core). It is interesting to note that $\mathrm{S}-\mathrm{Z}$ calculate the constitutional core in two dimensions, along the argument presented in Tsebelis and Chang (2004), using the first two dimensions from Laver and Hunt's (1992) book. Figure 6 depicts the relationship between sentence reversals and constitutional range, derived from S-Z's data. Indeed, as constitutional range increases, so too does the independence of the judiciary.

S-Z's analysis has been criticized by Fiorino et al. (2007). They consider the appointment process of the judges, and when they include their own set of variables, they claim that S-Z's findings (on which the analysis in this article relies) are reversed. Yet, as Fiorino et al. acknowledge, they do not consider constitutional decisions alone. They claim that 'The consideration of all types of decisions that the Court may undertake in reviewing legislation makes our analysis more adherent to reality' (Fiorino et al., 2007, 695). As a result, their dependent variable (unlike S-Z and this article) does not address constitutional decisions. In addition, in terms of their independent variable, they consider the 'Herfindahl index of the fragmentation of parties in the government coalition' (Fiorino et al., 2007, 692) as a proxy. However, this variable has nothing to do with the constitutional core used in this analysis (as well in the S-Z argument) for at least two reasons: first, it covers the government alone, and not the required two-third majority required by the constitution, and second, it is a function of the number of seats in Parliament that each governing party has, and not of policy positions. To make things clear, the Fiorino et al. variable depends on the distribution of seats in the government coalition: fragmentation increases the weak main coalition partner. On the other hand, the $S-Z$ variable of core size depends on the positions of the parties of the constitutional core (including the Communists), and increases when the distance between Communists and the most conservative government coalition 

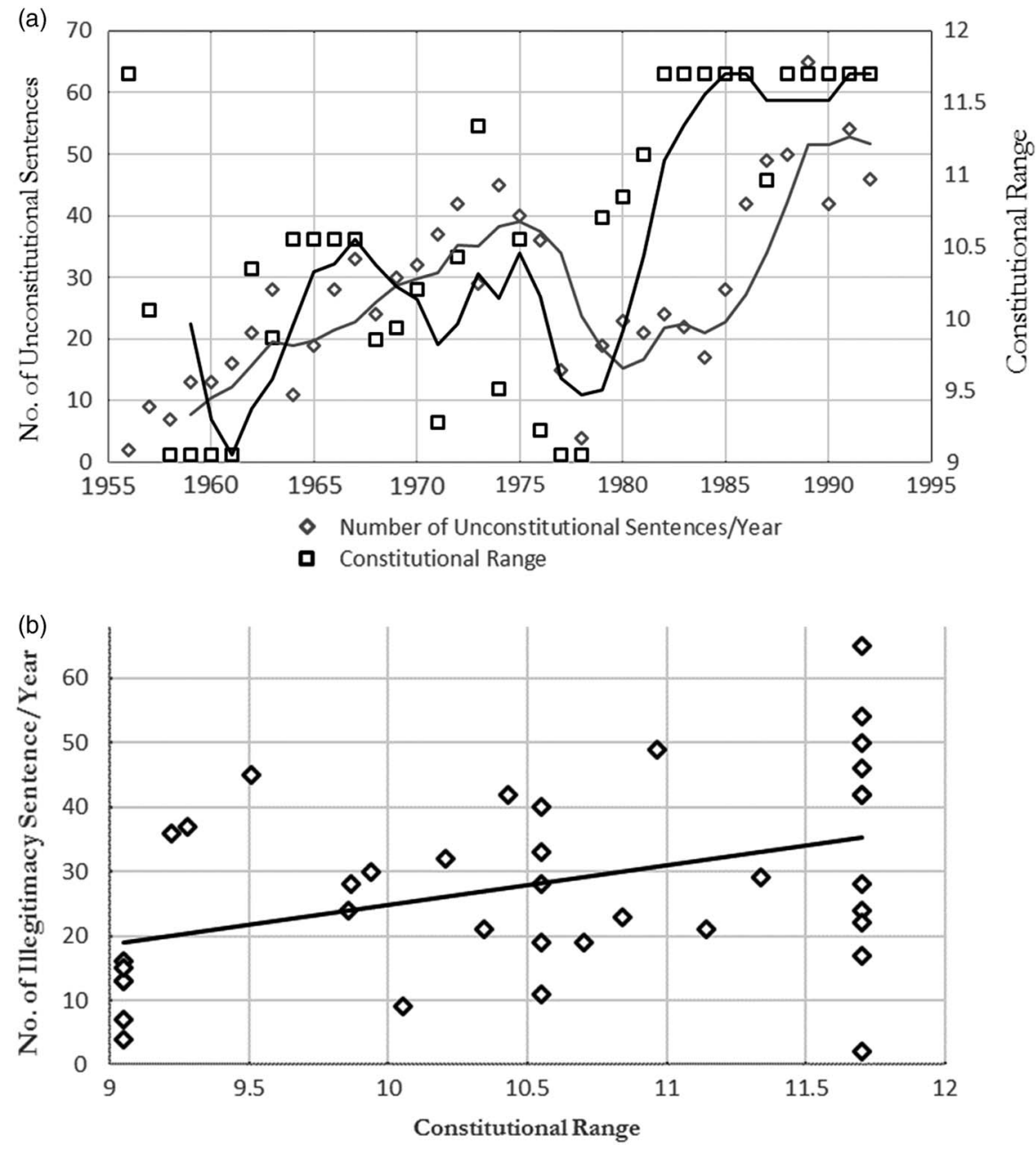

Figure 6 Core size and judicial independence in Italy.

partner increases. Consequently, the Fiorino et al. arguments (with different independent and dependent variables) not only do not invalidate but cannot be even considered relevant to the S-Z arguments or the arguments in this article. ${ }^{8}$

With regard to Italy's proposed constitutional reforms, then, both empirical and theoretical research suggests that judges' power of constitutional interpretation will increase. Indeed, because the reforms will render constitutional revision more

\footnotetext{
${ }^{8}$ In addition, while one may be sympathetic (as I am) to the argument that the origin of judges may affect their decisions, one has to be able to attribute decisions to different judges which in Italy is not possible because of vote confidentiality. Attributing decisions to the proportion of judges originating from the judiciary or the political system while these judges may have been in the dissenting minority without explaining the mechanism does not necessarily lead to valid conclusions.
} 


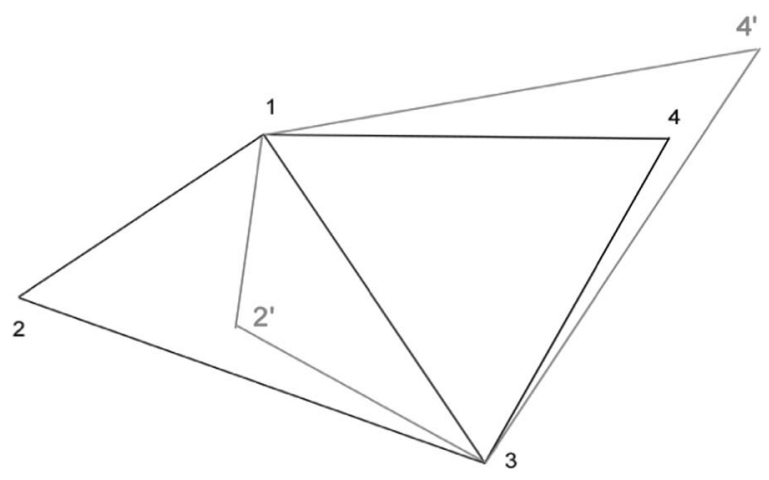

Figure 7 Legislative and constitutional cores, old and new.

difficult (growing the constitutional core), the judiciary will face fewer possibilities of constitutional revision for which the legislature could agree to overrule their decision. ${ }^{9}$ Figure 6 uses S-Z data to show the historical evolution of Constitutional Court decisions to invalidate government decisions on grounds of constitutionality, along with the size of the constitutional core. The two time series seem correlated, and the next pictures shows that the visual impression is correct: the independence of the court is correlated with the size of the constitutional core.

As a result of the proposed reforms, then, Italy would see two important changes that are relevant to the power of the judiciary, depicted in Figure 7. First, it would see a decrease in the size of its legislative core, shrinking from triangle 123 to 12 ' 3. This would limit the courts' power in statutory interpretation. However, the reforms would also increase the size of the constitutional core, growing from quadrilateral 1234 to 1234'. This would empower the courts, in terms of constitutional interpretation.

\section{Conclusions}

Italy is poised to potentially enact perhaps its largest constitutional reforms since the ratification of its constitution in 1947. Mired in political instability and indecision for much of its modern constitutional history, reformers hope that the proposed changes to the constitution will allow for more policy change and government stability. This article has applied the principles of veto players analysis to assess the impacts of the proposed constitutional reforms on politics and governance in Italy. These principles suggest three basic sets of consequences for Italy. First, policy change would become easier and more frequent in Italy, as a result of the removal of the Senate as a veto player - exactly as the reform intended. The impact of this change on economic

\footnotetext{
9 Amending the constitution to overrule a Constitutional Court is rare, but possible. Here, I remind the reader of the so-called 'Fair Trial' constitutional act of 1999 to argue that, while this sort of reactionary amendment is rare, its threat is credible.
} 
growth, however, is ambiguous, as changes to the status quo can be either good or bad for the economy. Second, the reforms would render future constitutional revision more difficult, locking the constitution in place. The reason is that symmetric bicameralism has been preserved on constitutional revisions, while the mode of election of the Senate may drive it further away from the House than in the past. It is important to note that this is not the only choice. The Austrian constitution provides a different example. In article 44, it restricts participation of the Senate on constitutional matters only on issues of federalism. ${ }^{10} \mathrm{~A}$ similar solution was not selected in the Italian case, and constitutional revisions are likely to become more difficult because of the selection of the Senate by local communities if the proposed reforms are approved by voters. Indeed, one may expect the present reform effort to be the last such successful effort for years to come if it is successful. Finally, my analysis finds that while shrinking the legislative core would lessen the power of Italian courts in statutory interpretation, growing the constitutional core would embolden the judiciary on matters of constitutional interpretation.

Taken together, the proposed constitutional reforms are necessary because the Italian political system has led to a stalemate. The fact that they could have been better in a specific and meaningful way does not alter the assessment that they will improve the ability of the political system to avoid immobilismo.

At this time, we do not know the result of the referendum. It may approve the constitutional revisions, or it may reject the amendments, along with the Renzi government. Even in the case of rejection of this constitutional reform, though, another one will likely be forthcoming, and a reduction in the multiplicity of veto players (most likely through the issue of bicameralism) will necessarily be in the forefront of the amendments.

\section{Acknowledgments}

The paper was written while the author was a Kellogg Visiting Fellow at the University of Notre Dame, and presented in the conference on Bicameralism and Constitutional Reforms of the Italian Society of Public Economics (SIEP). The author thank Prof. Michele Bernasconi for the invitation, and the participants for very interesting comments. The author also thanks Jesse Crosson for very efficient research assistance, and Francesco Zucchini for his guidance on historic intricacies of Italian politics.

\section{Financial Support}

The research received no grants from public, commercial, or non-profit funding agency.

10 '1. Constitutional laws or constitutional provisions contained in simple laws can be passed by the National Council only in the presence of at least half the members and by a two thirds majority of the votes cast; they shall be explicitly specified as such ('constitutional law', 'constitutional provision').

2. Constitutional laws or constitutional provisions contained in simple laws restricting the competence of the Laender in legislation or execution require furthermore the approval of the Federal Council which must be imparted in the presence of at least half the members and by a two thirds majority of the votes cast'. 


\section{References}

Acemoglu, D. and S. Johnson (2005), 'Unbundling institutions', Journal of Political Economy 113(5): 949-995.

Alesina, A. and A. Drazen (1991), 'Why are stabilizations delayed?', American Economic Review 81: 1170-1188.

Alesina, A. and R. Perotti (1995), 'Fiscal expansions and adjustments in OECD countries', Economic Policy 10(21): 205-248.

Andrews, J.T. and G.R. Montinola (2004), 'Veto players and the rule of law in emerging democracies', Comparative Political Studies 37(1): 55-87.

Angkinand, A.P. and T.D. Willett (2008), 'Political influences on the costs of banking crises in emerging market economies: testing the U-shaped veto player hypothesis', Macroeconomics and Finance in Emerging Market Economies 1(2): 279-297.

Fatás, A. and I. Mihov (2013), 'Policy volatility, institutions, and economic growth', Review of Economics and Statistics 95(2): 362-376.

Fiorino, N., F. Padovano and G. Sgarra (2007), 'The determinants of judiciary independence: evidence from the Italian constitutional court (1956-2002)', Journal of Institutional and Theoretical Economics JITE 163(4): 683-705.

Follain, J. (2015), 'Renzi wins vote to overhaul Roman Senate in blow to elite'. Bloomberg.com. Retrieved 7 June 2016 from http://www.bloomberg.com/news/articles/2015-10-13/renzi-wins-vote-to-overhaulroman-senate-in-blow-to-elite.

Franzese, R.J. (2002), Macroeconomic Policies of Developed Democracies, New York: Cambridge University Press.

Giuriato, L., A. Cepparulo and M. Barberi (2016), 'Fiscal forecasts and political systems: a legislative budgeting perspective', Public Choice 168(1-2): 1-22.

Hallerberg, M. and S. Basinger (1998), 'Internationalization and changes in tax policy in OECD countries the importance of domestic veto players', Comparative Political Studies 31(3): 321-352.

Hamilton, A., J. Madison and J. Jay ((1961) [1787-1788]), The Federalist Papers, Reprint New York: New American Library.

Henisz, W.J. (2000), 'The institutional environment for economic growth', Economics and Politics 12(1): $1-31$.

Henisz, W.J. and E.D. Mansfield (2006), 'Votes and vetoes: the political determinants of commercial openness', International Studies Quarterly 50(1): 189-212.

Kastner, S.L. and C. Rector (2003), 'International regimes, domestic veto-players, and capital controls policy stability', International Studies Quarterly 47(1): 1-22.

Kydland, F.E. and E.C. Prescott (1977), 'Rules rather than discretion: the inconsistency of optimal plans', The Journal of Political Economy 85: 473-491.

Laver, M. and W.B. Hunt (1992), Policy and Party Competition, New York: Routledge.

MacIntyre, A. (2001), 'Institutions and investors: the politics of the economic crisis in Southeast Asia', International Organization 55(1): 81-122.

McGrath, D.R. (1983), 'James Madison and social choice theory: the possibility of republicanism'. Unpublished Dissertation.

McLean, I. and A.B. Urken (1992), 'Did Jefferson or Madison understand Condorcet's theory of social choice?', Public Choice 73(4): 445-457.

The Economist (2015), 'Not just hand-waving'.. The Economist. Retrieved 7 June 2016 from http://www. economist.com/news/europe/21674774-italian-government-was-byword-instability-and-indecisionno-more-not-just-hand-waving.

O'Reilly, R.F. (2005), 'Veto points, veto players, and international trade policy', Comparative Political Studies 38(6): 652-675.

Roubini, N. and J.D. Sachs (1989), 'Political and economic determinants of budget deficits in the industrial democracies', European Economic Review 33(5): 903-933.

Santoni, M. and F. Zucchini (2004), 'Does policy stability increase the constitutional court's independence? The case of Italy during the first republic (1956-1992)', Public Choice 120(3-4): 439-461. 
Treisman, D. (2007), The Architecture of Government: Rethinking Political Decentralization, New York: Cambridge University Press.

Tsebelis, G. (2002), Veto Players: How Political Institutions Work, Princeton, NJ: Princeton University Press.

Tsebelis, G. (2016), ‘Constitutional rigidity: a veto players approach'. Unpublished Manuscript, University of Michigan, Ann Arbor.

Tsebelis, G. and J. Money (1997), Bicameralism, New York: Cambridge University Press.

Tsebelis, G. and E.C.C. Chang (2004), 'Veto players and the structure of budgets in advanced industrialized countries', European Journal of Political Research 43(3): 449-476. 